UDC 330.3:377.1

DOI https://doi.org/10.32840/1813-3401.2021.2.11

O. V. Shershnova

PhD in Public Administration, Lecturer at the Department of Document Science and Informational Activities National University of Ostroh Academy ORCID: 0000-0003-1582-4515

V. D. Bondar

$\mathrm{PhD}$ in Public Administration, Lecturer at the Department of Document Science and Informational Activities

National University of Ostroh Academy

ORCID: 0000-0002-2425-3884

K. I. Yakunina

$\mathrm{PhD}$ in Historical Sciences, Lecturer at the Department of Cultural Studies and Philosophy National University of Ostroh Academy ORCID: 0000-0002-2948-0429

\title{
EDUCATIONAL COMPONENT IN SDGS IMPLEMENTATION IN UKRAINE: REGIONAL ASPECT
}

Aim. This research trace connection between education and Sustainable Development Goals in Ukraine on the example of Rivne region. The purpose is to analyze the Sustainable Development Goals (SDGs) implementation and its educational component at regional level in Ukraine, which reflects the main educational trends in the country, the level of realization of civil rights and values, the tendencies in the SDGs implementation in general. Methods. The authors have conducted quality research with comparative, contextual and rating analysis of regional and local strategic development plans, key SDGs documents, and indicators of SDGs implementation.

Results. According to the results of reporting documents analysis on the implementation of Sustainable Development Strategies of Rivne region, it is appropriate to state that the mechanisms of SDG 4 implementation are: establishing partnerships between government officials, educational institutions, business associations, chambers of commerce, relevant enterprises, and civil society; the principle of complicity and joint participation; raising funds from international financial donors, donors; conducting an educational, informational and educational campaign in the community, etc. At the present universities have become a platform for the accumulation of ideas, human resources and a translator of SDGs ideas for the public. More, the regional authorities emphasized the importance of the educational component as a mechanism for addressing planned operational goals, but the SDG 4 implementation leaves much to be desired. Initiatives implemented within the SDG 4 remain declared or have the form of solving common problems.

Conclusions. The educational component in SDGs implementation at the regional level in Ukraine is only being formed and is insufficiently defined in activities of both educational institutions and public administration system of Sustainable Development. Complex analysis of Strategic Development Plans of Rivne region and reporting documents on its implementation shows (in)prospects and (in) effectiveness of the educational component as a mechanism for SDGs implementing in the region at present period of time.

Key words: sustainable development, Sustainable Development Goals, strategy, education, Rivne region.

Introduction. The emergence of Sustainable Development concept in the XX century became a new stage in solving the global problems of Man- kind. The implementation of ideas and principles of Sustainable Development, based on environmental balance, economic and social develop- 
ment, is carried out at all levels, including global, national, local, individual. Important in achieving the principles of Sustainable Development is the individual level, which is a person's awareness of the consequences of their own activities in changing the environment. Education, which is an important factor in the formation of environmental awareness among the inhabitants of the planet, significantly effects on individual level. At the present stage, it is advisable to trace the role of national education in understanding and promoting the concept of Sustainable Development and Sustainable Development Goals (SDGs).

The United Nations (UN) Conference on Environment and Development (The Earth Summit), held in Rio de Janeiro in 1992, launched the concept of Sustainable Development. Ukraine was one of the states that supported The Earth Summit's main documents - "The Rio Declaration on Environment and Development" and "Agenda 21" [14]. Agenda 21 aimed to promote sustainable development at global and national levels. This document became the basis for the formation of the 8 Millennium Development Goals (MDGs), and later for the Sustainable Development Goals. The UN Sustainable Development Summit in September 2015 , based on the MDGs, proposed a new package of global goals called the Sustainable Development Goals. They were enshrined in the final document of the Summit "Transforming our World: The 2030 Agenda for Sustainable Development". In total, 17 global goals and 169 tasks were set to be implemented and implemented in the world in 2015-2030. Ukraine joined the implementation, holding series of expert consultations at the national and regional levels for determining the priority and adaptation of the SDGs in 2016. As a result, the priority SDGs in Ukraine by 2030 were determined and ranged:

1. Goal № 16 (Building a peaceful and inclusive society);

2. Goal № 8 (Sustainable economic growth and decent work for all);

3. Goal № 3 (Good health and promotion well-being);

4. Goal № 9 (Sustainable infrastructure and innovation);

5. Goal № 1 (Poverty reduction) [18].

An Interdepartmental Working Group of Representatives of United Nation Development Program in Ukraine and the National Academy of Sciences of Ukraine was established to monitor and evaluate the achievements of the SDGs in Ukraine in 2018. Decree of the President of Ukraine № 722/2019 "On the Sustainable Development Goals of Ukraine until 2030" [7] provided dynamics in achievements the SDGs in Ukraine. According to this Decree, the SDGs are guidelines for the development of draft forecast and program documents, draft regulations in order to ensure the balance of economic, social and environmental dimensions of sustainable development of Ukraine. In pursuance of this Decree, the Ministry of Economic Development, Trade and Agriculture of Ukraine analyzed the incorporation of the SDGs into the strategic and program documents of the State. The analysis showed that a total of 17 goals and 86 national tasks of the SDGs are incorporated in 162 regulations of the Government. 1394 tasks and 4296 measures, enshrined in these acts, are aimed at implementing the tasks of the SDGs [20]. Thus, Sustainable Development Goals are being actively implemented in Ukraine at the national level.

The implementation of strategies begins at the regional level, which objectifies the study of this process from this level. Moreover, the problems faced by local governments, civil society organizations and civil society in the region in the process of implementing SDG 4 become an indicator of thelevel ofquality ofeducationand togetherprovide an opportunity to try such mechanisms to improve the educational environment that would not work at the national level.

Despite the significant efforts of the United Nation Development Program (UNDP) and Ukrainian Government agencies, the concept of Sustainable Development, understanding and promotion of the SDGs remains unclear to the majority of the population of Ukraine. This is especially true for regional and local development. According to the data of Analytical report on the results of the National Sociological Survey "Perceptions of the population of Ukraine about Sustainable Development", made in March 2017, $57,3 \%$ of the respondents do not hear about SDGs in Ukraine, that is a factor that slows down the process of achieving them at the individual and local I evels [18].

To study the SDGs implementation in Ukraine at national, and regional levels, it is important to determine the range of scientists who are engaged or whose research is relevant to this issue. So, main authors, whose researches were conducted to Sustainable Development Goals implementation and its indicators on national and regional strate- 
gies in Ukraine are: Artemenko V. [1], Gerasimchuk Z. [3], Gromozdova L., Gromozdov V. [17], Smyrnova I., Mykhailiuta Ye. [8], and others. In Ukraine a number of scientists have been formed, who study certain aspects of the SDGs implementation in the activities of institutions and establishments at both national and regional levels, in particular, Omarov Sh. [4], Shershnova O. [13], Vysotska O. [2], and others. Therefore, the question of the educational component inclusion for SDGs implementation at the regional level remains partially investigated, and it will be interesting for further research and comprehensive analysis within the current study.

Objectives and methodology. The purpose of this research is to analyze the Sustainable Development Goals implementation and its educational component at regional level in Ukraine, which reflects the main educational trends in the country, the level of realization of civil rights and values, the tendencies in the SDGs implementation in general. Education in Sustainable Development is directly related to all its economic, social, political and informational components. The educational mechanisms in a particular country make it possible to trace the general level of education and to determine the problems of SDGs implementation in it.

Main tasks of this research are to identify mechanisms for SDG 4 implementation in strategic documents in Rivne region and to analyze the level of educational component of Sustainable Development Goals at the regional level. The choice of the region is explained by the direct inclusion of the research group members in the educational space of both Ukraine and the Rivne region.

This paper analyses the theoretical framework of SDGs, its manifestations in Ukraine and Rivne region since it needs contextualization - how it works on regional level. Main methods, used for performing research tasks, were chosen as comparative, contextual and rating analysis of regional and local strategic development plans, key SDGs documents, and indicators of SDGs implementation.

Results. The basis for understanding and consolidating the ideas of sustainable development in society is education. In 1992, at the UN Conference on Environment and Development in Johannesburg, education was recognized as a "tool" for achieving sustainability and the idea of holding the UN Decade of Education for Sustainable Development was adopted. The main goal of the Decade was to integrate the concept of Sustainable Development into national education systems at all levels. In particular, in Chapter 36 of the "Agenda 21" we can find the opinion that a necessary condition for the implementation of the concept of Sustainable Development is to increase the level of educational development [14].

In 2003, at the conference "Environment for Europe" in Kyiv, environment ministers from 55 countries around the world decided to develop a regional strategy for education for Sustainable Development. In 2005, the United Nations Economic Commission for Europe (UNECE) presented the document "Education Strategy for Sustainable Development" [15]. The Strategy identified the main approaches to the implementation of Sustainable Development in the education sector, the involvement and training of specialists, the need to move the education of knowledge to education until 2015.

An important international document is the Resolution A/RES/74/223 "Education for sustainable development in the framework of the 2030 Agenda for Sustainable Development" (2019) [16], where one of the identified targets for SDGs in education by 2030 is "to ensure equal access for all women and men to low-cost and high-quality technical, vocational and higher education, including universities", as well as in the Reports on of Sustainable Development Goals achievement in Ukraine (2020).

Terms "Education for Sustainable Development", "Education in the interests of Sustainability", "Education of Sustainability" become more recognizable in the XXI century. Thus, a survey conducted among EU citizens in 2012 showed that " $70 \%$ of respondents expressed a desire to learn, at the same time, $80 \%$ believe that education should improve their professional life, and $72 \%$ personal" [21].

The standard tool for a general comparison of living standards of different countries and regions, or its individual indicators (education, health, ecology, etc.) is the monitoring of key indicators. Integrated monitoring and reporting systems have been introduced to assess the level of the SDGs implementation, including its educational component at various levels. Important sources of information about Sustainable Development Goal's implementation are SDG Tracker, SDG Indicators Metadata repository, SDG 4 Indicators and ESDToolkit, etc. For example, indicators of Sustainable Development Goals Implementation in Ukraine by SDG Tracker 
are presented at Table 1. The data show that in Ukraine there are quite high indicators that have been achieved.

Indicators of SDGs Implementation in Ukraine are decisive for indicators at the regional level. The research team decided to compare them to track their implementation at different levels of public administration. So, strategic planning and in accordance with the SDGs (MDGs until 2015) Rivne region began in 2011 with the Sustainable Development Strategy of Rivne region "Western Gate" for 20112014 and its Implementation Plan (2011) [6]. Having identified economic, environmental and social development as strategic goals for the region's development, focusing on MDG 1 (poverty reduction), MDG 2 (providing quality lifelong learning), and MDG 7 (sustainable environmental development), the regional authorities emphasized the importance of the educational component as a mechanism for addressing planned operational goals. Namely:

- supporting of applied research activities in educational institutions;

- flexible mediation between enterprises, educational institutions and the labor force, especially the unemployed;

- improving the quality of educational services, their compliance with the needs of the labor market, creating mechanisms for flexible balancing of supply and demand in the labor market;

- encouraging young people to return and stay in their rural community after getting an education in the city;
- creation of opportunities for continuous quality education and improvement of skills, including lifelong learning, etc.

Strategic planning of Rivne region in the following periods was focused on the development of economic potential of the region, balanced regional development, and the development of human capital $[11 ; 12]$. These goals were correlated with the SDGs.

The educational component in their implementation concerned:

- development of social, communal and educational infrastructure of villages;

- improving training for the needs of the regional economy, including the development of a lifelong learning system;

- development of innovation culture by popularizing the implementation of scientific, inventive and innovative activities, as well as the creation of a holistic education system, taking into account the staffing of innovative activities;

- formation of modern centers of vocational education with the introduction of new technologies for priority sectors of the regional economy, etc.

According to the results of the analysis of reporting documents on the implementation of Sustainable Development Strategies of Rivne region, it is appropriate to state that the mechanisms of implementation of SDG 4 are (Table 2):

- establishing partnerships between government officials, educational institutions, business

Table 1

Indicators of Sustainable Development Goals Implementation in Ukraine by SDG Tracker

\begin{tabular}{|c|c|}
\hline Indicator & Ukraine \\
\hline $\begin{array}{c}\text { Share of students at end of lower secondary education } \\
\text { achieving minimum maths proficiency, 2010-2015 }\end{array}$ & $81 \% 2015$ \\
\hline $\begin{array}{c}\text { Proportion of children under 5 years of age who are developmentally } \\
\text { on track, 2015 }\end{array}$ & $89 \%$ under-5s 2012 \\
\hline Total net enrolment rate, primary, gender parity index (GPI), 2015 & 1.02 GPI 2014 \\
\hline School life expectancy, primary, gender parity index (GPI), 2015 & 1.02 GPI 2014 \\
\hline Primary completion rate, gender parity index (GPI), 2015 & 1.02 GPI 2014 \\
\hline School life expectancy in secondary education, males, 2014 & 6.94 years 2014 \\
\hline School life expectancy in secondary education, males, 2014 & 6.82 years 2014 \\
\hline School life expectancy in secondary education, males, 2014 & $99,72 \%$ \\
\hline Youth literacy rate, female, 2015 & $99,81 \%$ \\
\hline Adult literacy rate, population 15+ years, male (\%), 2015 & $99,79 \%$ \\
\hline Adult literacy rate, population 15+ years, female (\%), 2015 & $99,74 \%$ \\
\hline Gross overseas development assistance (ODA) & $\$ 10.84$ billion \\
\hline from all donors for scholarships, 2015 & $84,76 \% 201$ \\
\hline Percentage of teachers in primary education who are qualified, 2015 & \\
\hline
\end{tabular}


associations, chambers of commerce, relevant enterprises, and civil society; the principle of complicity and joint participation;

- raising funds from international financial donors, donors;

- conducting an educational, informational and educational campaign in the community, etc.

However, it should be noted that the implementation of SDG 4 in Rivne region was mainly implemented through the optimization of the network of educational institutions and the improvement of their material and technical base; systematic monitoring of the labor market and coordination of training programs with the needs of the labor market; cooperation with universities in the training of highly qualified personnel, in demand in the innovative components of economic development. Therewith, such promising measures as "mixed planning of areas such as "housing - work - education - social infrastructure" or "formation of a single information educational environment" have not been fully implemented [11]. The educational component is used as a mechanism to solve economic, environmental, social problems of the region, but the implementation of SDG 4 leaves much to be desired. Initiatives implemented within the SDG 4 remain declared or have the form of solving common problems. This is why indicators of Sustainable Development Goals Implementation in Rivne region are defined as "described partly".

Indicators of Sustainable Development Goals Implementation in Rivne Region (no data in 2020) are:

- number of established preschool educational institutions;

- number of organized activities for the rehabilitation and recreation of children;

- number of educational and cultural campaigns activities for young people to respond to today's challenges;

- percentage of retention in the workplace of graduates received specialty;

- number of established youth centers;

- share of employed citizens over the age of 45 and vulnerable groups population;

- number of educational activities aimed at increasing ecological culture and education of citizens [12].

Table 2

Educational component of the implementation of the CSW of Rivne region in 2011-2020

\begin{tabular}{|c|c|c|}
\hline & Strategic goals & Operational goals, objectives \\
\hline $\begin{array}{l}\text { Sustainable } \\
\text { Development } \\
\text { Strategy of Rivne } \\
\text { region "Western } \\
\text { Gate" for 2011-2014 }\end{array}$ & $\begin{array}{l}\text { 1. Economic development } \\
\text { 2. Ecological development } \\
\text { 3. Social development }\end{array}$ & $\begin{array}{c}\text { 3.4. Improving conditions for improving the quality } \\
\text { of life in the region } \\
\text { 3.4.3. Improving opportunities for youth self- } \\
\text { organization } \\
\begin{array}{c}\text { 3.4.4. Creating opportunities for continuing quality } \\
\text { education and skills development, including } \\
\text { lifelong learning }\end{array} \\
\end{array}$ \\
\hline $\begin{array}{l}\text { Development } \\
\text { Strategy of Rivne } \\
\text { region for the period } \\
\text { up to } 2020\end{array}$ & $\begin{array}{l}\text { 1. Development of economic } \\
\text { potential "Region of sustainable } \\
\text { economic growth" } \\
\text { 2. Development of rural areas "Equal } \\
\text { Opportunities Region" } \\
\text { 3. Development of human capital } \\
\text { "The land of comprehensive human } \\
\text { development" }\end{array}$ & $\begin{array}{c}\text { 2.3. Supporting rural employment } \\
\text { 2.3.3. Improving training for small businesses in } \\
\text { rural areas } \\
\text { 3.1. Increasing the adaptability of the population } \\
\text { to the needs of the labor market } 3.1 .1 \text {. Improving } \\
\text { the system of preparing young people for } \\
\text { the conditions of the regional labor market } \\
\text { 3.1.2. Improving training for } \\
\text { the needs of the regional economy, including } \\
\text { the development of a lifelong learning system }\end{array}$ \\
\hline $\begin{array}{l}\text { Development Strategy } \\
\text { of Rivne region for } \\
\text { the period up to } 2027\end{array}$ & $\begin{array}{l}\text { 1. Development of a competitive } \\
\text { economy } \\
\text { 2. Balanced development } \\
\text { of the territories of region } \\
\text { 3. Development of human capital }\end{array}$ & $\begin{array}{c}\text { 3.1. Raising awareness and social activity } \\
\text { of residents } \\
\text { 3.1.1. Improving the educational level of young } \\
\text { people, providing citizens with equal conditions for } \\
\text { access to quality education } \\
\text { 3.1.2. Promoting the social development of young } \\
\text { people, volunteering and comprehensive } \\
\text { protection and development of children, respect for } \\
\text { human rights and gender equality } \\
\text { 3.1.3. Improving training for the needs } \\
\text { of the regional economy and social sphere, } \\
\text { supporting leadership development }\end{array}$ \\
\hline
\end{tabular}


At the present stage of SDGs implementation in the region, universities have become a platform for the accumulation of ideas, human resources and a translator of ideas for the public. This is why, within the activities of the Joint UNDP/EU Project "Community Based Approach to Local Development" (CBA), comprehensive consultations were held on the SDGs implementation and building sustainable partnerships of higher education institutions in their achievement, for example creation of the network "Educational Network for Sustainable Local Development", which included 42 universities of Ukraine [5].

Importantly, that SDG 4 "Quality Education" is somehow decelerated in the strategies of universities in Rivne region, in particular, in "Ostroh Academy-450. Development Strategy of the National University of Ostroh Academy for 2017-2026" [9], "Development Strategy of the Rivne State University for the Humanities until 2025" [10]. Strategic documents of universities are characterized by declarative and descriptive mechanisms for achieving strategic priorities. There is also a partial compliance of local documents with the strategic priorities of the region, which is a temporary phenomenon, but needs further analysis.

Thereby, the SDGs implementation in the regions should be correlated with the level of their economic and social development. So, SDG 4 implementation should become an accessible mechanism for solving other correlated local and regional problems. Quality, accessible education should be an end in itself, not a "simple way out". Under such conditions, universities in their strategic documents reflect how to make full use of the potential of education for regional development.

Conclusions and perspectives of research. Therefore, the educational component in Sustainable Development Goals implementation at the regional level in Ukraine is only being formed and is insufficiently defined in activities of both educational institutions and public administration system of sustainable regional development. Comparative, contextual and rating analysis of the Strategic Development Plans of Rivne region and reporting documents on its implementation shows (translates) (in)prospects and (in)effectiveness of the educational component as a mechanism for implementing the SDGs in the region at present period of time. This situation is typical for countries in transition, which could be defined as countries, where education is the most sup- ported by state with partial consideration of global trends and slow response of the state system to the fluctuation and uncertainty of external circumstances.

Determination of the current state and trends of certain Sustainable Development Goals implementation in strategic documents and operational plans of higher education institutions of Ukraine in comparison with international experience, as well as the use of implementation indicators for harmonizing state statistical reporting are promising for further in-depth analysis.

\section{References:}

1. Артеменко В. Індикатори стійкого соціальноекономічного розвитку регіонів. Регіональна економіка. 2006. № 2. С. 90-97.

2. Висоцька О. Освіта для сталого розвитку : науково-методичний посібник. Дніпропетровськ, 2011. 200 c.

3. Герасимчук 3. Регіональна політика сталого розвитку: методологія формування, механізми реалізації. Луцьк, 2001. 528 с.

4. Омаров Ш. Оценка устойчивого развития регионов Украины. Проблемы экономики. 2014. № 3. С. 139-150.

5. Освітня мережа сприяння сталому місцевому розвитку: унікальний досвід дієвого мережевого партнерства ВНЗ України. 2018. URL: https:// dspace.uzhnu.edu.ua/jspui/handle/lib/20046.

6. План реалізації стратегії сталого розвитку Рівненської області «Західна Брама» на 2011-2014 pp. URL: http://www.old.rv.gov.ua/ sitenew/main/ua/publication/content/4654.htm 2011.

7. Про Цілі сталого розвитку України на період до 2030 р. : Указ Президента України № 722/2019. URL: https://www.president.gov.ua/ documents/7222019-29825.

8. Смирнова І., Михайлюта $Є$. Сталий розвиток в Україні: теоретичні аспекти. Економічний вісник Донбасу. 2018. № 1 (51). С. 10-14.

9. Стратегія розвитку НаУОА на 2017-2026 pp. URL: https://www.oa.edu.ua/ua/ info/access/strategichnuy_plan_rozvytku.

10.Стратегія розвитку Рівненського державного гуманітарного університету до 2025 p. URL: http://www.rshu.edu.ua/images/rshu/stratehia_ rozvitku_rshu.pdf.

11. Стратегія розвитку Рівненської області на період до 2020 p. URL: https://www. rv.gov.ua/storage/app/sites/11/oktober2019/ strategiya2020.pdf.

12.Стратегія розвитку Рівненської області на період до 2027 p. URL: https://www. rv.gov.ua/storage/app/sites/11/022020/1618strategia-2027.pdf. 
13.Шершньова О. Інформаційно-комунікаційні технології та цілі в галузі сталого розвитку на період до 2030 р. Інформація та культура в забезпеченні сталого розвитку людства : збір. матер. міжнар. наук.-практ. конференції, м. Маріуполь, 4 листопада 2015 р. С. 174-175.

14.Agenda 21. URL: https://sustainabledevelopment. un.org/content/documents/Agenda21.pdf.

15. Education for Sustainable Development / United Nations Educational, Scientific and Cultural Organization. URL: https://en.unesco.org/themes/ education-sustainable-development.

16. Education for Sustainable Development in the framework of the 2030. Agenda for Sustainable Development. Resolution A/RES/74/223 adopted by the General Assembly on 19 December 2019 / United Nations. URL: https://undocs.org/ en/A/RES/74/223.

17.Gromozdova L., Gromozdov V. Global goals of Sustainable Development in the regional policy of Ukraine. International Economic Policy. 2017. Vol. 2. P. 168-182.

18.Implementing the 2030 Sustainable Development Goals in Ukraine: analysis of government strategies and public policy. Executive Summary of the Analytical Study by Institute for Social and Economic Research. 2017. URL: http://iser.org. ua/uploads/files/ISED_Resume-ENG_v07\%20 FINAL.pdf.

19.SDG Tracker. URL: https://sdg-tracker.org/qualityeducation.

20.Sustainable Development Goals Ukraine. Voluntary National Survey. 2020. URL: https:// sustainabledevelopment.un.org/content/ documents/26295VNR_2020_Ukraine_Report. pdf.

21.Towards an institutional strategy for Lifelong Learning in Higher Professional Education. FLLLEX consortium, May 2012. URL: www.aqu.cat/doc/doc_16974883_1.pdf.

\section{Шершньова О. В., Бондар В. Д., Якуніна К. І. Освітній компонент у впровадженні ЦСР в Україні: регіональний аспект}

Стаття присвячена дослідженню освітнього компонента у впровадженні Цілей сталого розвитку в Україні на прикладі Рівненської області. Мета дослідження - проаналізувати виконання Цілей сталого розвитку (в контексті освіти) на регіональному рівні в Україні, головні освітні тенденції в країні, рівень реалізації громадянських прав і цінностей у ній. Освітній компонент сталого розвитку суспільства безпосередньо пов'язаний із економічними, соціальними, політичними його складниками. Механізми, за допомогою яких освітній компонент впроваджується в конкретній країні, дозволяють простежити загальний рівень освіти у ній та ті проблеми, з якими пов'язана реалізація Цілей сталого розвитку.

Відповідно до проведеного порівняльного та контекстуального аналізу Стратегій розвитку Рівненської області за 2011, 2015, 2020 рр., звітів і планів реалізації Стратегії, зіставивши досягнуті цілі на регіональному рівні та в Україні за допомогою індикаторів, автори дійшли висновку, що механізмами виконання Цілей сталого розвитку $4 €$ : співпраця держустанов з освітніми установами, громадськими організаціями, підприємництвом; дотримання принципу співучасті і спільної участі; залучення коштів міжнародних фрінансових донорів, грантова діяльність; проведення просвітньої, інфрормаційної й освітньої кампанії в суспільстві. Заклади вищої освіти стали платформою для накопичення ідей, людських ресурсів і трансляторами ідей сталого розвитку в соціумі. До того ж, місцева влада акцентує увагу на важливості освітнього компонента Цілей сталого розвитку як механізму для реалізації планових оперативних цілей. Водночас ініціативи, розпочаті в контексті СРС 4, залишаються більшою мірою проголошеними, а не повністю реалізованими.

Отже, освітній компонент у впровадженні Цілей сталого розвитку на регіональному рівні в Україні лише проходить становлення та $€$ не досить визначеним як у діяльності закладів освіти, так і в системі державного управління сталим регіональним розвитком. Такий стан характерний для держав, що перебувають на етапі перехідної економіки та визначаються як країни, де освіта найбільше підтримується державою з частковим урахуванням світових тенденцій і повільним реагуванням системи управління на фрлукацію і невизначеність зовнішніх обставин.

Ключові слова: сталий розвиток, Цілі сталого розвитку, стратегія, освіта, Рівненська область. 